\title{
1D Compressibility of DMS Treated With Cement-GGBS Blend
}

\author{
Suaathi Kaliannan ${ }^{1 a}$, Chee-Ming Chan ${ }^{2}$, Azeanita Suratkon ${ }^{2}$ \\ ${ }^{1}$ Master's Student, University of Tun Hussein Onn Malaysia, 86400, Parit Raja, Johor, Malaysia \\ ${ }^{2}$ Senior Lecturer, University of Tun Hussein Onn Malaysia, 86400, Parit Raja, Johor, Malaysia
}

\begin{abstract}
Great quantities of dredged marine soils (DMS) have been produced from the maintenance of channels, anchorages and for harbour development. DMS have the potential to pose ecological and human health risks and it is also considered as a geowaste. Malaysia is moving towards the sustainability approach and one of the key factors to achieve it is to reduce waste. Thus, this geowaste should be generated as a new resource to substitute soil for civil works such as for land reclamation and backfilling. This shows the improved settlement of consolidation in treated DMS. DMS is referred to as a cohesive soil which includes clayey silt, sandy clay, silty clay and organic clay. This type of soil has low strength and high compressibility. The objectives were achieved through literature review analysis and also laboratory test which was one dimensional oedometer test. On the other hand, treated DMS with more ground granulated blast furnace slag (GGBS) gives a lower settlement compared to specimen with higher percentage of cement in a treated soil. Thus this shows that cement content can be reduced in soil solidification when GGBS is added. The optimum binder ratio found was 3:7 where 3 is cement and 7 is GGBS.
\end{abstract}

\section{Introduction}

Dredging can be described as underwater excavation of soils. It is essential to maintain existing coastal areas, ports and water channels. The need of increase in waterway depths might be due to the increased demand for transporting by water. Besides that, dredging process is also used in flood control measures to maintain or improve the river or channels flow capacities. The soil dislodged from the waterways, whether from the sea, river or port is known as dredged soil. Mostly, such dredged materials consist of sands, silts, clay and other material from underwater [1-4]. The dredged soils are very similar to soft clay on land, with low loadbearing capacity, high compressibility and low permeability. These properties make the soil unsuitable for construction activities. Besides, continuous disposal of the material, whether offshore on inland, does not promote sustainable practice, considering that the material could be reused, and that the dumping procedures almost always destroys one or other environmental concerns [5]. Thus, if the dredged material is to be reused as a geo- material, the naturally weak and soft soil needs to be treated. A possible solution is the solidification technique, where binders are admixed with the wet soil to dry and stiffen it chemically. A journal reports the use of improved soil (a mixture of dredged soil and converter slag) for land reclamation in Japan [6]. This is an example of evidence that dredged materials can be treated to improve its

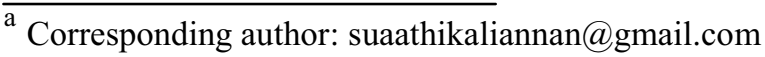

suitability, either by improving its environmental properties or providing economic benefits [7].

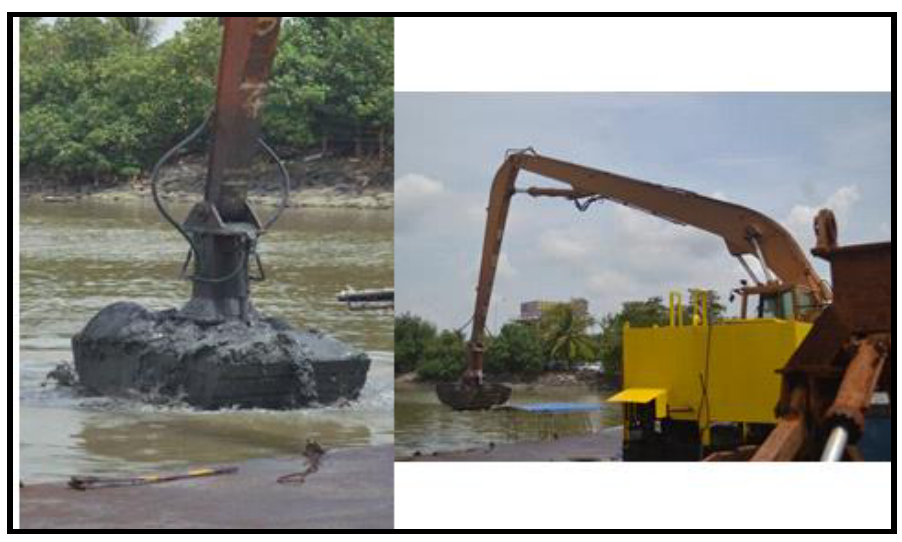

Figure 1. Clamshell Dredger

\section{Sample Collections}

The soil samples were collected from Kuala Perlis, Perlis. The soils were dredged from the sea by using clamshell dredger. The soils were dredged at $6-7 \mathrm{~m}$ depth from the sea level. The dredged soil was temporarily stored in a barge. The soils were scooped out from the barge and placed into the sampling buckets and then transported from Kuala Perlis to laboratory. The soil samples were stored at UTHM laboratory. The soils were stored indoors to avoid sunlight and heat. 


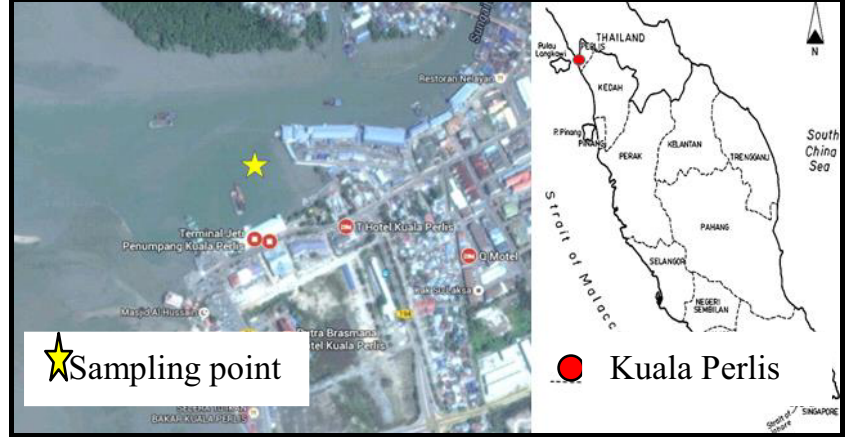

Figure 2. Location of samples collected

High temperature of surrounding area can destroy the organic matter, causing loss of mass, contributes to water loss and result in the inaccuracy of moisture content measurement. Then the soils were transferred from sampling bucket to 5 covered storage containers.

\section{DMS Classification}

Physical and chemical characterisations are important for describing the properties of DMS. Basic characteristics of the soil were obtained using the classification test referring to British Standard. Table 1 shows the physical and chemical characteristics of DMS sample. DMS consists of $11 \%$ silt, $38 \%$ sand and $51 \%$ of clay as seen in Figure 3. According to Unified Soil Classification System (USCS), DMS falls in High Plasticity clay (CH) category.

Table 1. Soil Classification Result

\begin{tabular}{|c|c|}
\hline Parameters & Values \\
\hline Moisture Content & $147 \%$ \\
\hline Specific Gravity & 2.66 \\
\hline Liquid Limit & $70 \%$ \\
\hline Plastic Limit & $33.33 \%$ \\
\hline Plasticity Index & $36.67 \%$ \\
\hline Loss on Ignition & 10.6 \\
\hline pH & 7.28 \\
\hline Soil Classification & $\mathrm{CH}$ \\
\hline
\end{tabular}

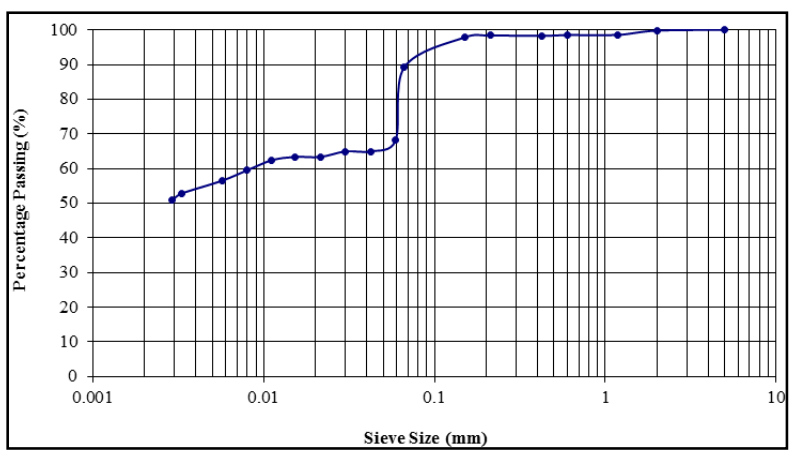

Figure 3. Particle size distribution of DMS

\section{Types of Solidifying Agent}

The binders are cement and ground granulated blast furnace slag (GGBS). Cement was acquired from UTHM's laboratory while GGBS was provided by YTL Corporation from the Pasir Gudang plant. All the materials were oven dried for 24 hours at $105^{\circ} \mathrm{C}$ and kept in an air-tight container.

\subsection{Cement}

Cement solidification has been widely used to improve the engineering properties of the clayey soils [8-10]. Cement is a hydraulic type solidifying agent. According to [11], there are two major chemical reactions which are induced by the addition of cement to clay and govern the soil cement solidification process which are the primary hydration reaction of the cement and water, and the secondary pozzolanic reactions between the limes released by the cement and the clay minerals. These cement particles bind the adjacent cement grains together during hardening and form a hardened skeleton matrix, which covers virgin soil particles. Many studies have focused on using cement-treated dredged soil for ground improvement. [8,12-14] studied the characteristics of soft clay treated cement and found that treating soft clay with a little quantity of cement can effectively reduce settlement. Cement acts as an additive and improves the quality of soil for the purpose of increasing strength and durability.

\subsection{Ground Granulated Blast Furnace Slag}

GGBS is a by-product from the blast-furnaces used to make iron. These operate at a temperature of about 1,500 degrees centigrade and are mixed with a carefully controlled mixture of iron-ore and limestone. The iron ore is reduced to iron and the remaining materials form a slag that floats on top of the iron. This slag is consistently tapped off as a molten liquid and if it is to be used for the manufacture of GGBS it has to be rapidly quenched in large volumes of water. The quenching optimises the cementitious properties and produces granules similar to coarse sand. [15]. This 'granulated' slag is then dried and ground to a fine powder. The major use of GGBS is in ready-mixed concrete. In the production of ready-mixed concrete, GGBS replaces a certain portion of the normal cement content, generally about $50 \%$ to $70 \%$. The higher the proportion, the better is the durability. The disadvantage of the higher replacement level is that earlyage strength development is somewhat slower GGBS is not only used in concrete and other applications include the in-situ solidification of soil. In South Africa, ggbs activated lime, is commonly used in binder for soil solidification [16] and there is 40 years of experience of its use.

\section{Curing Period}

The improved engineering properties of cement-treated soils are mainly attributed to the cement hardening effect. It is due to hydration, where the moisture of the soil 
reacts with cement for example curing period. Due to pozzolanic reaction with time, it is generally accepted that the longer the curing period, the better the strength development. The curing time also has an effect on the specimens in consolidated-drained triaxial compression test, with a longer curing time leading to a lower strain to peak strength and higher peak strength for the specimens[10]. The 7-day strength increases almost proportionately with the cement content throughout the range of cement content investigated in the test of unconfined compressive strength of treated clays [17]. As reported by [18], cement-treated Singaporean marine clay showed significant curing effect in the physical properties, unconfined compressive strength and compressibility characteristics, such as the decrease of compression index $(\mathrm{Cc})$ with longer curing period.

\section{Details of Test Specimens}

Table 2 shows the proportions of binders added to the DMS. All the amounts were calculated using dry weight of DMS. Percentage of DMS was maintained at $100 \%$ for each test. The curing period for each specimen is 7 days.

Table 2. Test specimen for binders + DMS

\begin{tabular}{|c|c|c|c|c|c|c|c|}
\hline \multirow{2}{*}{$\begin{array}{c}\text { Mix } \\
\text { Propo } \\
\text {-rtion } \\
\text { (C:G ) }\end{array}$} & \multicolumn{3}{|c|}{$\begin{array}{c}\text { Cement } \\
\text { content } \\
(\mathrm{g})\end{array}$} & \multicolumn{3}{|c|}{$\begin{array}{c}\text { GGBS } \\
\text { content } \\
\text { (g) }\end{array}$} & \multirow[b]{2}{*}{ Specimen } \\
\hline & $\begin{array}{l}10 \\
\%\end{array}$ & $\begin{array}{l}20 \\
\%\end{array}$ & $\begin{array}{l}30 \\
\%\end{array}$ & $\begin{array}{l}10 \\
\%\end{array}$ & $\begin{array}{l}20 \\
\%\end{array}$ & $\begin{array}{l}30 \\
\%\end{array}$ & \\
\hline $0: 0$ & - & - & - & - & - & - & 0C0G_\# \\
\hline $0: 100$ & 0 & 0 & 0 & 20.4 & 40.8 & 61.2 & 0C10G_\# \\
\hline $15: 85$ & 3.06 & 6.13 & 9.20 & 17.4 & 34.7 & 52.0 & $\begin{array}{c}1.5 \mathrm{C} 8.5 \mathrm{G} \\
\#\end{array}$ \\
\hline $30: 70$ & 6.12 & 12.3 & 18.4 & 14.3 & 28.6 & 42.9 & 3C7G_\# \\
\hline $70: 30$ & 14.3 & 28.6 & 42.9 & 6.12 & 12.3 & 18.4 & 7C3G_\# \\
\hline $100: 0$ & 20.4 & 40.8 & 61.2 & 0 & 0 & 0 & 10C0G_\# \\
\hline
\end{tabular}

\section{One -Dimensional Consolidation Test}

The consolidation test, also called as one dimensional oedometer test, is used to estimate the amount of settlement under a structured load. According to BS13775:1990, Test 3, this method covers the determination of the magnitude and the rate of the consolidation of a saturated specimen of soil in the form of disc confined laterally, subjected to vertical axial pressure, and allowed to drain freely from the top and bottom surfaces. In this test, the soil specimen is loaded axially in increments of applied stress. Each stress increment is held constant until the primary consolidation has ceased. During this process water drains out of the specimen, resulting in a decrease in height which is measured at suitable intervals. These measurements are used for the determination of the relationship between compression (or strain) or voids ratio and effective stress, and for the calculation of parameters which describe the amount of compression and the rate at which it takes place. The test procedure is conducted according to the BS 1377-5:1990, clause 3.0.

\subsection{Preparations of Specimens}

The DMS were mixed with the required amount of binders at their natural water contents. DMS and binders were thoroughly mixed in a conventional food mixer according to the mix ratios. In order to avoid spillage, the food mixer was initially run at a low speed for 1 minute. After that, the mixing process was stopped to scrape off the materials stucked on the mixing paddle and sides of the bowl. Then, the mixing process was resumed for 4 minutes, where a homogeneous clay-additive paste was formed by then. The total mixing process took approximately 5 minutes, as recommended by [19]. The mixture was next compacted into the consolidation ring of $75 \mathrm{~mm}$ diameter and $20 \mathrm{~mm}$ height. The total amount of mixture needed to be compacted into the ring was approximately $160 \mathrm{~g}$. It is to standardize the densities of oedometer specimens to ensure a fair assessment of the test results. The mixture was divided into 2 lumps of $80 \mathrm{~g}$ each. Each lump was tamped 40 times by hand with a tamping rod to form a layer in the ring. After compaction of the 2 layers, the end of specimen was trimmed flat by using straight edged spatulas. The test specimen was in the form of a disc of proportions specified for the consolidation ring in which it is to be tested. The specimens with binders were left to cure for 7 days.

\section{Results and Discussions}

\subsection{Analysis of $t_{50}$ and $t_{90}$}

Theoretically $t_{50}$ and $t_{90}$ can be identified in all plots of settlement curves but practically $t_{50}$ and $t_{90}$ could not be determined in every plot of settlement curves. Table $3(a, b, c)$ shows the data of $t_{50}$ from all the samples and note that some samples could not be derived. If the specimen has sustained a certain load previously, and a smaller or same load is being applied again, the settlement curve will not have the immediate settlement, primary and secondary consolidation stages. The higher the percentage of binders, the higher the pressure needed to be applied. It is observed in time settlement plot that when a specimen is solidified, it takes a larger load to show a visible settlement process. For example in a specimen which has $10 \%$ binders, an evident time plot curve can be seen when $25 \mathrm{kPa}$ of load is applied unlike specimen with $20 \%$ binders, the clear settlement process begins to appear at the load of $50 \mathrm{kPa}$. As for the specimen with $30 \%$ binders, the clear curve can be seen only after 200 or $400 \mathrm{kPa}$. 
Table 3 Compilation of data for all specimens

\begin{tabular}{|c|c|c|c|c|c|c|}
\hline \multicolumn{7}{|c|}{ a) $\mathbf{5}_{\mathbf{5 0}}(\mathbf{1 0} \%$ binders $)$} \\
\hline $\begin{array}{c}\text { Load } \\
\mathbf{k P a})\end{array}$ & $\mathbf{D M S}$ & $\begin{array}{c}\mathbf{0 C} \\
\mathbf{1 0 G}\end{array}$ & $\begin{array}{c}\mathbf{1 . 5 C} \\
\mathbf{8 . 5 G}\end{array}$ & $\begin{array}{c}\mathbf{3 C} \\
\mathbf{7 G}\end{array}$ & $\begin{array}{c}\mathbf{7 C} \\
\mathbf{3 G}\end{array}$ & $\begin{array}{c}\mathbf{1 0 C} \\
\mathbf{0 G}\end{array}$ \\
\hline 12.5 & 32 & 25 & 3.5 & 7 & 11 & 1.8 \\
\hline 25 & 20 & 38 & 10 & 17 & 11 & 7.5 \\
\hline 50 & 20 & 25 & 7.5 & 16 & 42 & 7 \\
\hline 100 & 15 & 18 & 5.5 & 8 & 42 & 4.5 \\
\hline 200 & 14 & 18 & 9 & 9.5 & 45 & 5.2 \\
\hline 400 & 12 & 7.5 & 3.5 & 4.5 & 33 & 4.3 \\
\hline 800 & 8.5 & 6.5 & 3.8 & 3.5 & 17 & 4.8 \\
\hline
\end{tabular}

\begin{tabular}{|c|c|c|c|c|c|c|}
\hline \multicolumn{7}{|c|}{ b) $\mathbf{t}_{\mathbf{5 0}}(\mathbf{2 0} \%$ binders $)$} \\
\hline $\begin{array}{c}\text { Load } \\
\mathbf{k P a})\end{array}$ & $\mathbf{D M S}$ & $\begin{array}{c}\mathbf{0 C} \\
\mathbf{1 0 G}\end{array}$ & $\begin{array}{c}\mathbf{1 . 5 C} \\
\mathbf{8 . 5 G}\end{array}$ & $\begin{array}{c}\mathbf{3 C} \\
\mathbf{7 G}\end{array}$ & $\begin{array}{c}\mathbf{7 C} \\
\mathbf{3 G}\end{array}$ & $\begin{array}{c}\mathbf{1 0 C} \\
\mathbf{0 G}\end{array}$ \\
\hline 12.5 & 32 & 25 & - & 49 & - & - \\
\hline 25 & 20 & 38 & - & 1.4 & - & - \\
\hline 50 & 20 & 25 & 2.5 & 2 & 2.1 & 3.4 \\
\hline 100 & 15 & 18 & 4 & 3.8 & 5.6 & 2.7 \\
\hline 200 & 14 & 18 & 6.5 & 2 & 3.5 & 4 \\
\hline 400 & 12 & 7.5 & 4 & 7.5 & 7 & 8 \\
\hline 800 & 8.5 & 6.5 & 4 & 10 & 5.4 & 4 \\
\hline
\end{tabular}

\begin{tabular}{|c|c|c|c|c|c|c|}
\hline \multicolumn{7}{|c|}{$\mathbf{t}_{\mathbf{5 0}}(\mathbf{3 0} \%$ binders $)$} \\
\hline $\begin{array}{c}\text { Load } \\
(\mathbf{k P a})\end{array}$ & $\mathbf{D M S}$ & $\begin{array}{c}\mathbf{0 C} \\
\mathbf{1 0 G}\end{array}$ & $\begin{array}{c}\mathbf{1 . 5 C} \\
\mathbf{8 . 5 G}\end{array}$ & $\begin{array}{c}\mathbf{3 C} \\
\mathbf{7 G}\end{array}$ & $\begin{array}{c}\mathbf{7 C} \\
\mathbf{3 G}\end{array}$ & $\begin{array}{c}\mathbf{1 0 C} \\
\mathbf{0 G}\end{array}$ \\
\hline 12.5 & 32 & 50 & - & - & - & - \\
\hline 25 & 20 & 60 & - & - & - & - \\
\hline 50 & 20 & 80 & - & - & - & 1.5 \\
\hline 100 & 15 & 25 & 8 & 1.1 & - & 4.5 \\
\hline 200 & 14 & 16 & 5.5 & 1.7 & 2 & 6 \\
\hline 400 & 12 & - & 10 & 1.4 & 1.8 & 15 \\
\hline 800 & 8.5 & 4 & 16 & 1.7 & 2.1 & 90 \\
\hline
\end{tabular}

\subsection{Comparison of Compression Curves}

Referring to Figure 4, 5 and 6 the percentage of binders added was $10 \%, 20 \%$ and $30 \%$ respectively. Binders refer to cement $(\mathrm{C})$ and ground granulated blast furnace slag $(\mathrm{G})$ In all the figures, data of $3 \mathrm{C} 7 \mathrm{G}, 7 \mathrm{C} 3 \mathrm{G}, 10 \mathrm{C} 0 \mathrm{G}$, $0 \mathrm{C} 10 \mathrm{G}, 1.5 \mathrm{C} 8.5 \mathrm{G}$ and $0 \mathrm{C} 0 \mathrm{G}$ were compared. The ratios are $3: 7,7: 3,10: 0,0: 10,1.5: 8.5$ and $0: 0$ In Figure 4, specimen $3 \mathrm{C} 7 \mathrm{G}, 7 \mathrm{C} 3 \mathrm{G}$ and $1.5 \mathrm{C} 8.5 \mathrm{G}$ does not show much difference whereas $10 \mathrm{C} 0 \mathrm{G}$ remained as the lowest settlement value. This may be due to the percentage of binders $(10 \%)$ which is quite minimal, thus the obvious reaction could not be noticed. The reaction most probably occurred because of the cement hydration process and also the percentage of binder was too small to activate the reaction in the specimen. On the other hand, Figure 5 and 6 have more or less the same pattern but different value of settlement. Specimen 3 C7G in both graphs has a lower settlement compared to the other specimens with value of $14 \%$ and $9 \%$ each. Specimen $3 \mathrm{C} 7 \mathrm{G}$ of both figure 5 and 6 has greater yield strength despite of lower cement content in it.

Initially specimen $3 \mathrm{C} 7 \mathrm{G}$ recorded more settlement as time goes it can be observed that plot of $7 \mathrm{C} 3 \mathrm{G}$ had a drastic drop which is nearly twice of the value of $3 \mathrm{C} 7 \mathrm{G}$ specimen in both figure 7 and 8 . Besides, specimen $0 \mathrm{C} 10 \mathrm{G}$ which does not contain any cement mixture in all 3 figures shows a very poor resistance towards the load applied. This is because GGBS itself is not as reactive as when cement is added to it. Overall settlement reduction is shown by specimen $3 \mathrm{C} 7 \mathrm{G} \_20 \%$.

The compression index $(\mathrm{Cc})$ of this specimen is 0.015 where it is the lowest if compared among the other specimens in binder percentage of 20 . Even though specimen $3 \mathrm{C} 7 \mathrm{G} \_30 \%$ has a lower $\mathrm{Cc}$ value which is 0.009 but the settlement reduction of specimen $3 \mathrm{C} 7 \mathrm{G} \_20 \%$ is sufficient thus raw materials and cost can be cut down. In general both specimens exhibited a decrease in the compression index in their respective binder percentage but not in a large scale. This can be observed in figure 7.

When soil undergoes compressive force, the development of hydration is destroying the structure and furthermore water is being dissipated, thus consolidation effects overwhelmed the. development of structure. This overall shows that a lower cement content mixed with a higher ratio of GGBS helps in lowering the settlement value. The United Kingdom it's quite common to replace between 40 and $70 \%$ of cement[20]. Cement has an apparent activation energy of $34 \mathrm{~kJ} / \mathrm{mol}$ while this figure increases to $60 \mathrm{~kJ} / \mathrm{mol}$ when a binder consisting of $70 \%$ GGBS and 30\% Portland Cement was used [21].

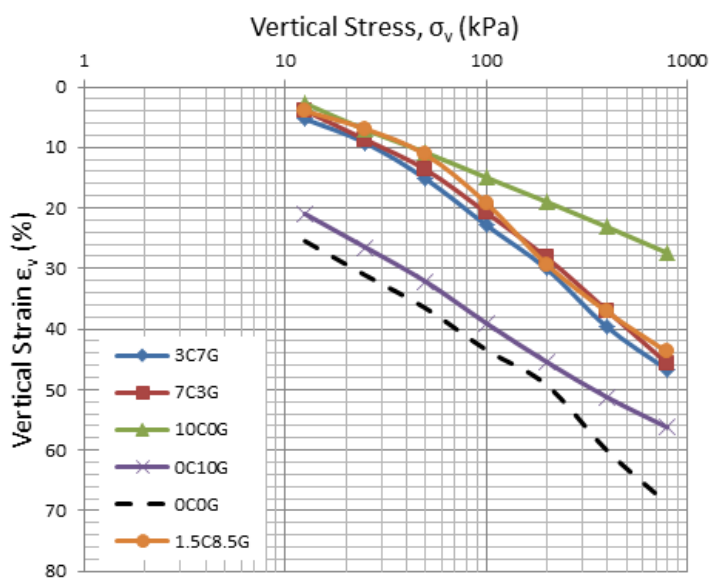

Figure 4. Compression curve of $10 \%$ binders 


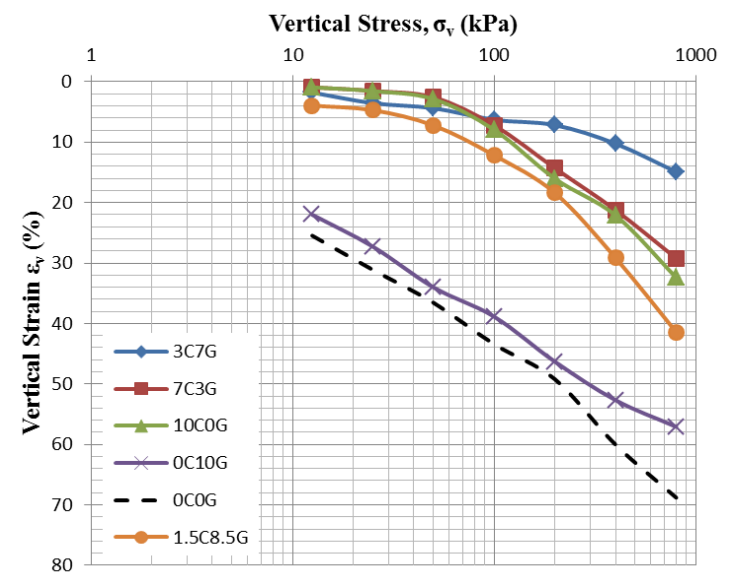

Figure 5. Compression curve of $20 \%$ binders

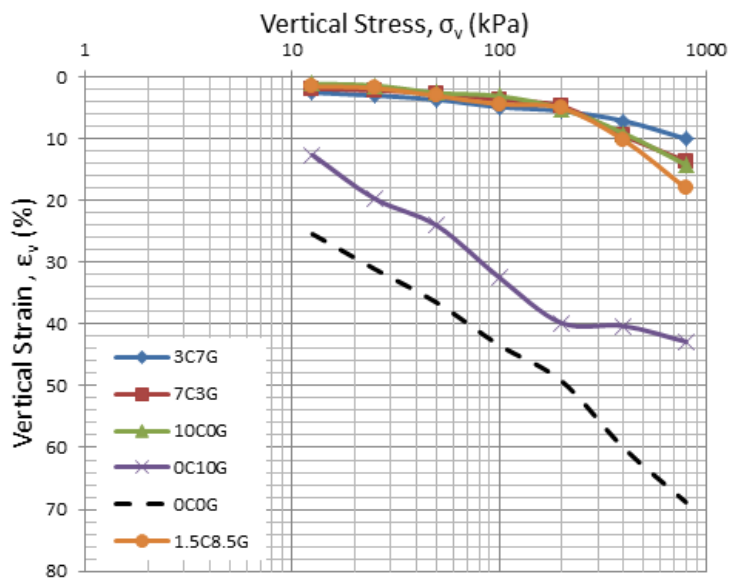

Figure 6. Compression curve of $30 \%$ binders

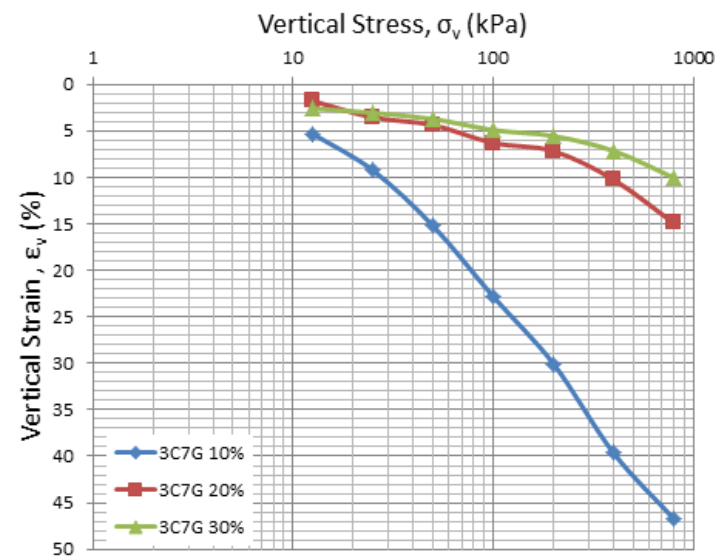

Figure 7. Comparison of Compression curve of $3 \mathrm{C} 7 \mathrm{G}$ of $10 \%$, $20 \%$ and $30 \%$ of binders

\subsection{Cement Ratio Effects}

Referring to Figure 8, x-axis represents the cement dosage in a binder which affects the choice of an optimum binder whereas $y$-axis shows the final settlement of each specimen according to percentage of the binders. Binders are combination of cement and GGBS. Figure 8 shows the ratio for $10 \%, 20 \%$ and $30 \%$ of total binder. So, notice that in Figure 8 the plot for $10 \%$ specimen is unclear as the percentage of binder is insufficient for the binder to react towards the soil whereas for plot of $20 \%$ and $30 \%$ binder, it is seen that there is an optimum ratio of cement portion which is 3 . Apparently, cement ratio with 3 of $20 \%$ binder shows the optimum and a visible difference in the entire cement portion as seen in Figure 8. From this plot can be concluded that any cement portion less than 3 or more than 3 is not good. Thus the optimum mixture of binder is determined from these plots which are $20 \%$ binder and cement portion of 3 . Material usage can be saved for onsite application and it will be also cost-effective and less pollution.

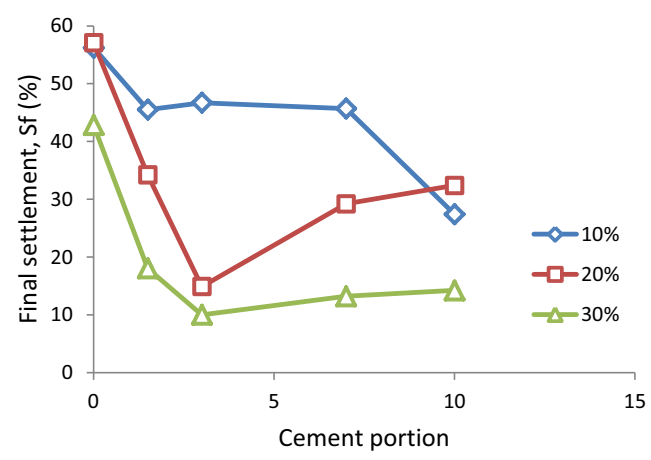

Figure 8. Comparison of Cement dosage in 10\%, $20 \%$ and 30 $\%$ binders

\subsection{Coefficient of volume compressibility $\left(m_{v}\right)$ of DMS + Binders}

The coefficient volume of compressibility $\left(\mathrm{m}_{\mathrm{v}}\right)$ is influenced by the chemical and physical properties of soil materials such as clay mineral composition, particle size, pore water chemistry, organic matter etc. Based on Figures 9-11, the analysis of various values of vertical effective stress, the coefficient of volume compressibility $\left(\mathrm{m}_{\mathrm{v}}\right)$ values, for all solidified DMS specimens have been determined.

For DMS specimen, the value of $\mathrm{m}_{\mathrm{v}}$ decreases from $203 \mathrm{~cm}^{2} / \mathrm{kN}$ to $30 \mathrm{~cm}^{2} / \mathrm{kN}$ as the pressure increases from $12.5 \mathrm{kPa}$ to $800 \mathrm{kPa}$, which shows that volume of compressibility of soil decreases with the increase of effective stress. Specimens with more percentage of binders are less compressible. It can be observed that $0 \mathrm{C} 10 \mathrm{G}$ specimens of all percentage of binders has more or less the same pattern of plots with the DMS specimen which shows that GGBS alone is not giving a stiffening effect to the soil. The $\mathrm{m}_{\mathrm{v}}$ for DMS specimen is 203 $\mathrm{cm}^{2} / \mathrm{kN}$ and it is in the range of $>15 \mathrm{~cm}^{2} / \mathrm{kN}$ classified as very high compressibility clay referring to Bella (2007). The $\mathrm{m}_{\mathrm{v}}$ value varies between $203 \mathrm{~cm}^{2} / \mathrm{kN}$ to $1 \mathrm{~cm}^{2} / \mathrm{kN}$ for various percentages of binders. The specimen that has lowest values of $\mathrm{m}_{\mathrm{v}}$ in $20 \%$ and $30 \%$ of binder is $3 \mathrm{C} 7 \mathrm{G}$ which shows that the specimen is stiffer compared to other specimens. A significant trend of decrease in the value of $m_{v}$ with the increase of stress was observed but the decreasing rate is smaller as the percentage of binders increased. This can be attributed to the addition of cement to the DMS because the stiffer the soil the less 
compressible it will be. Volume compressibility of soil decreases with cement stabilization. Besides, $m_{v}$ decreases with increase in consolidation pressure.

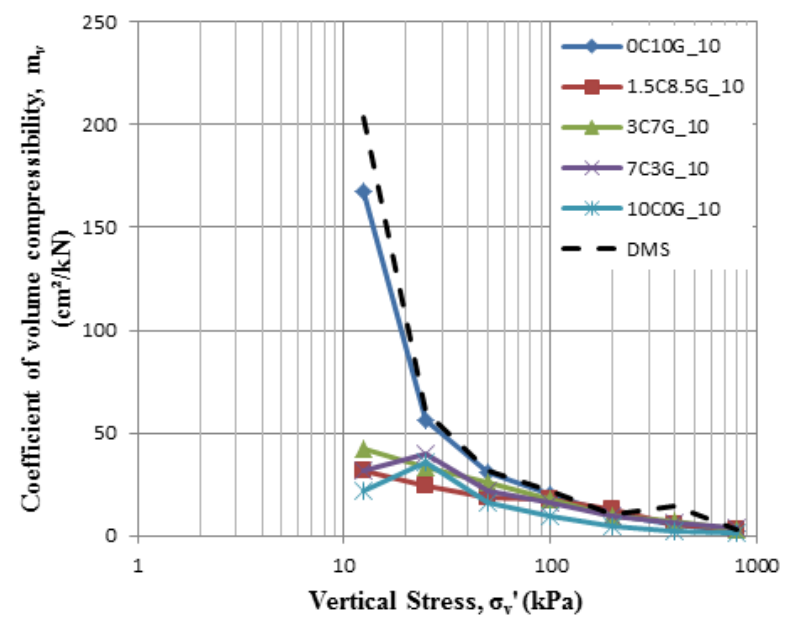

Figure 9. Coefficient of volume compressibility in DMS + Binder (10\%)

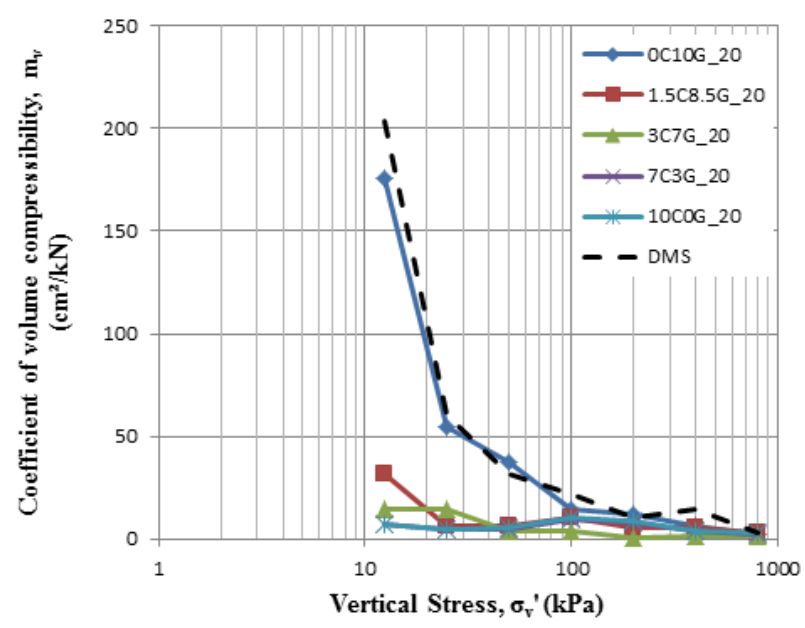

Figure 10. Coefficient of volume compressibility in DMS + Binder $(20 \%)$

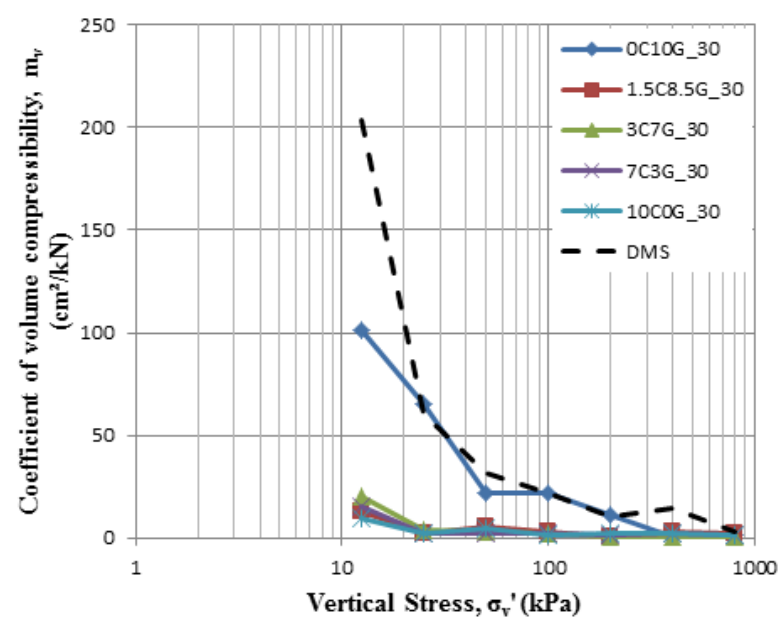

Figure 11. Coefficient of volume compressibility in DMS + Binder $(30 \%)$

\section{Conclusion}

Solidification is a method which aims to improve the engineering properties of the soil. Without solidification, DMS has a very low stiffness, low loadbearing capacity, high compressibility and low permeability. The mixing of cement and GGBS helped to improve the characteristics of the DMS. The optimum binder content for the best solidification result was identified which is $3 \mathrm{C} 7 \mathrm{G} \_20 \%$ specimen. As seen GGBS gives an effective replacement to cement but it cannot replace cement completely. But even though it replaces partially it gives very good results and a greener approach in construction and sustainable development.

\section{Acknowledgement}

Author thank authorities of Universiti Tun Hussein Onn Malaysia for providing the laboratory facilities and also to the field and laboratory staff. This work was supported by Office for Research, Innovation, Commercialization and Consultancy Management (ORICC), UTHM.

\section{References}

1. Vinothkumar, R., \& Arumairaj, P. D. Green Stabilization of Coimbatore Clay, 2(11), 234240.Christine R. 1999. The Eye of the BeholderDesigning for Colour-blind Users. British Telecommunications Engineering. 17: 291-295. (2013).

2. Wang, D., Abriak, N. E., \& Zentar, R. Strength and deformation properties of Dunkirk marine sediments solidified with cement, lime and fly ash. Engineering Geology, 166, 90-99. doi:10.1016/j.enggeo.2013.09.007.(2013).

3. Azhar, A., Chan, C., \& Abdkarim, A. T. Solidification Potential of Fine-Grained Dredged Marine Soils: Water-Binder Ratio Effects, 4, 4853. doi:10.5923/c.jce.201402.07. (2014).

4. Jong, S., \& Chan, C. The Fundamental Compressibility Characteristics of Solidified Dredged Marine Soil, 597-603(2013).

5. Butt, T. E., Lockley, E., \& Oduyemi, K. O. K.. Risk assessment of landfill disposal sites--State of the art. Waste Management (New York, N.Y.), 28(6), 952-64. doi:10.1016/j.wasman.2007.05.012. (2008).

6. Matsumoto.A, Tanaka.y, Nakagawa.M, Hiroki.k and Yamagoshi.Y Land reclamation using calcium oxide (cao) improved soil in japan. An information update from the Terra et Aqua,134. (2014).

7. IADC "Trailing Suction Hopper Dredgers", Factsabout - An information update from the IADC - Number 1 - 2014, International Association of Dredging Companies (IADC). (2014).

8. Feng, T. W., Lee, J.Y. \& Lee, Y. J. Consolidation Behaviour of A Soft Mud Treated With Small 
Cement Content. Journal of Engineering Geology (59): Elsevier Ltd., pp. 327-335. (2001).

9. Lorenzo, G. A. \& Bergado, D. T. Fundamental Characteristics of Cement-Admixed Clay in Deep Mixing. Journal of Materials in Civil Engineering, Vol. 18, No. 2: ASCE, pp. 161-174. (2006).

10. Xiao, H., \& Lee, F. Curing time effect on behavior of cement treated marine clay. Int. J. Eng. Phys. Sci, 2(7), 427-434. (2009).

11. Bergado, D.T., Anderson, L.R., Miura, N. \& Balasubramaniam, A.S. Soft Ground Improvement In Lowland And Other Environments. New York: ASCE Press. (1996).

12. Watabe, Y., Tsuchida, T., Furuno, T., and Yuasa, H. "Mechanical characteristics of a cement treated dredged soil utilized for waste rec- lamation land fill." Coastal geotechnical engineering in practice,A. Nakasa and T. Tsuchida, eds., Balkema, Rotterdam, Netherlands, 739-745(2000).

13. Miura, N., Horpibulsuk, S. \& Nagaraj, T.S.. Engineering behavior of ce- ment stabilised clay at high water content. Soils and Foundations, Vol. 41, No. 5, pp. 33-45. (2001).

14. Kim CK, Cho WB, Lee SL, Choi WJ A study on the Consolidation Characteristic of Cohesive Soil by Plastic Index. J. Korean Geotech. Society., 24(8): 99-109. (in Korean) (2008).

15. Ha. W., \& Velu Saraswathy,. Studies on the corrosion resistance of reinforced steel in concrete with ground granulated blast-furnace slag-An overview. Journal of Hazardous Materials, 138(2), 226-233. doi:10.1016/j.jhazmat.2006.07.022.(2006).

16. Sherwood, P.T.,. Effect of sulphates on cement and lime treated soils, HRB Bull. No. 3531982 pp. 98107. (1982)

17. Chew, S. H., Kamruzzaman, a. H. M., \& Lee, F. H. Physicochemical and Engineering Behavior of Cement Treated Clays. Journal of Geotechnical and Geoenvironmental Engineering, 130(7), 696-706. doi:10.1061/(ASCE)1090-0241(2004)130:7(696) .(2004).

18. Kamaruzzaman, A. H. M., Chew, S. H. \&Lee, F. H. Engineering behaviour of cement treated Singapore marine clay. Department of Civil Engineering, National University of Singapore, Paper 1190. (1998).

19. EuroSoilStab. Development of Design and Construction Methods to Stabilize Soft Organic Soils (Design Guide Soft Soil Stabilization). Brussels: CT97-0351. (2002).

20. Higgins, D. Soil stabilisation with ground granulated blastfurnace slag. UK Cementitious Slag Makers Association (CSMA), (September), 1-15. Retrieved from http://www.ukcsma.co.uk/files/csma report_on_soil_stabilisation.pdf. (2005).

21. Barnett, S. J., Soutsos, M. N., Millard, S. G., \& Bungey, J. HStrength development of mortars containing ground granulated blast-furnace slag: Effect of curing temperature and determination of apparent activation energies. Cement and Concrete
Research, 36(3), 434-440.

doi:10.1016/j.cemconres.2005.11.002. (2005). 